Relations industrielles

Industrial Relations

\title{
Union Security in Great Britain
}

\section{Gérard Dion}

Volume 4, numéro 6, février 1949

URI : https://id.erudit.org/iderudit/1023498ar

DOI : https://doi.org/10.7202/1023498ar

Aller au sommaire du numéro

\section{Éditeur(s)}

Département des relations industrielles de l’Université Laval

\section{ISSN}

0034-379X (imprimé)

1703-8138 (numérique)

Découvrir la revue

Citer cet article

Dion, G. (1949). Union Security in Great Britain. Relations industrielles /

Industrial Relations, 4(6), 57-58. https://doi.org/10.7202/1023498ar

Tous droits réservés @ Département des relations industrielles de l’Université Laval, 1949
Ce document est protégé par la loi sur le droit d'auteur. L’utilisation des services d'Érudit (y compris la reproduction) est assujettie à sa politique d'utilisation que vous pouvez consulter en ligne.

https://apropos.erudit.org/fr/usagers/politique-dutilisation/ 


\title{
UNION SECURITY IN GREAT BRITAN
}

\author{
Gérard Dion
}

Because of the close ties existing between Canada and Great Britain, British institutions exercise a considerable influence on those of our country. So there are not lacking so-called informed and reputedly competent persons who, in discussion on the problems of union security, state with surprising assurance that the closed shop does not exist in England. The Reverend Father Jerome Toner, Professor of Industrial Relations at St. Martin's College, Olympia, Washington, has just published an interesting study on this subjec ${ }^{+}$ entitled, «The Closed Shop in Great Britain. » ${ }^{1}$

The principle and practice of compelling all those who devote themselves to a business or exercise a trade to stick to their professional grouping as condition sine qua non of their work were accepted from the eighth to the eighteenth century in England as in all other European countries. No conflict between the individual right to work and the requirements of professional well-being were seen.

It was only in 1799 under the influence of laissez-faire liberalism that the closed shop and, at the same time, the right of association disappeared following a legal measure (39, Geo. III, c. 81$)$. But after 1800 the law was modified in such a way as to allow the worker \& to refuse to work with another for just and reasonable cause ». - It is the the closed shop in practice. - The fraternal societies, formed after the disappearance of the guilds, believed that the principle of the closed shop was their birthright and tried to impose them even by violence. So the law which in 1824 made legal the existence of labour unions, in one of its sections, forbade the practice of the closed shop (5, Geo. IV, c. 95). As often happens, legal prohibitions, when they go too far, produce effects contrary to those intended by the legislation. So, as W. T. Thornton $^{2}$ shows, in spite of legal prohibitions, the closed shop continues to exist and to spread so much that in certain places the employer cannot even hire his nephew or his brother without their becoming members of the union.

(1) Jerome Toner, "The Closed Shop in Great Britain", a brochure of 18 pages published by Labor's NonPartisan League, 907 Fifteenth St., N.W., Washington 5

(2) W.T. Thornton, On Labor, p. 207.
During the last half of the nineteenth century public opinion and the laws of 1867, 1871 and 1875 turned in favour of trade unions and permitted the closed shop such as it was conceived of in England i.e. the right for workers to refuse to work with anyone not a member of a union. There were legal proceedings on the question and the Privy Council, in the famous case of Allan vs Flood, confirmed definitely the practice of the closed shop. It became then so general, so much part of the customs that, to employ the words of Sydney and Beatrix Webb, «this constraint ceases to be apparent. A person not belonging to the union dares not even think of applying for a job, nor would he have the chance of obtaining one. $\gg^{3}$

In 1927, after the General Strike, the Trade Disputes and Trade Union Act was modified so as to abolish the practice of the closed shop in the entreprises directed by the State; however nothing was changed in other concerns and it continued to be general everywhere else.

We know that in 1946 the Labour Government again amended the law, not without considerable discussion, and re-established the legality of the Closed Shop for all enterprise. This is understandable because in Great Britain contrary to what we have here in Canada under the inflence of the "Industrial Relations and Disputes Investigation Act»(11-12 Geo. VI, c. 4), and in the Province of Quebec with the «Labour Relations Act» (Chap. 162A, 1944) a union does not have to be certified and does not have to possess the majority of the workers in the establishment as members in order to be allowed to treat in the name of all the employees. In addition, it is generally the associations of employers who negotiate collective agreements. Thus for the employers the possibility of influencing the choice of the uzion amongst the workers is much greater. Which has for consequence - the public services being under the domination of the Labour party and many basic industries being nationalized - that they have talked in certain surroundings of the «fascistization» of the labour unions. «The written concensus of opponents of the closed shop

(3) Sydney \& Beatrix WeBb, "Industrial Democracy", p. 216. 
seems to be that the child which has grown up to be the Government, and which soon may be the largest employer in Great Britain, will use the closed shop through the Trades Union Congress to perpetuate itself and crush all opposition. » ${ }^{4}$
But this political debate does not at all affect private enterprise where the closed shop remains a practice accepted by all to the point where they do not even take the trouble to include it as a special clause in collective labour agreements.

(4) Jerome Toner, op. cit., p. 15.

LABOUR EDUCATION

\section{THE EDUCATIONAL SERVICE OF THE C.C.C.L.}

\section{FERnand Jolicoeur}

The Canadian and Catholic Confederation of Labour (La Confédération des Travailleurs Catholiques du Canada) comprises to-day close to 90,000 members. It has become a commonplace to say that it is now the most representative labour movement in the Province of Quebec. This continuous expansion is as much due to the competence and the devotion of its organizers and technicians as to the value of the principles which animate it.

Facing this accomplished fact and the unknown future a prob!em is presented for the C.C.C.L. (C.T.C.C.) that of consolidating definitely the position acquired before directing its action towards the single aim it should pursue and which can assure it life, that aim which the social doctrine of the Church points out. In order to state precisely this aim, to make it known in all the labour movement, and to train its members to seek after it «by the easiest and shortest way », the C.C.C.L. has founded its own Educational Service.

One cannot imagine a trade union movement, much less one of Christian inspiration, without an organization for instruction. Moreover, the story of the C.C.C.L. amply proves that it hat not departed from this principle. From its beginnings we meet with study groups where were trained the leaders who brought about its present stature.

At Quebec, Monsieur l'abbé Maxime Fortin, first chaplain of the C.C.C.L., organized about 1915 what he called the "Commission des Questions Ouvrières de l'Action Sociale Catholique». At Montreal, Monsieur l'abbé Edmour Hébert, with the aid of the "École Sociale Populaire», founded in 1918 the famous Leo XIII Club considered as the first union study group of the movement. In each region of the Province these examples were followed with good results and towards 1938 the \& Fédération des Cercles d'Etudes » of the C.C.C.L. was formed. This latter functioned until 1946 when they commenced to think of a more elaborate organization better suited to the new needs of the labour world.

They sought after a formula while they awaited the financial means needed to start a real educational service where a full-time employee could direct the work and guide the studies on all the necessary levels. At the C.C.C.L. Congress at Hull, in October last the long-cherished project finally took form. The Educational Service of the C.C.C.L. came into existence and an officer of the movement took charge at the beginning of November last.

To explain the nature and the rôle of this new service it must be said, first of all, that it was not a school where the instructors would dispense learning that the C.C.C.L. wished to found but rather a center for studying together. As the name well expresses it, this will be a «service 》 organized to direct, to compile and to diffuse studies, a service to which will contribute all the leaders of the movement and from which will profit all the workers.

This new union service should not content itself with the initiating into unionism, indispensable as this is, nor with the training of negotiators, but, above all should explain the profound meaning of unionism, the reason and the essential direction of the labour movement.

Now the C.C.C.L. takes its stand on the social doctrine of the Church, to affirm that the present structure of society must be radically reformed. And it believes that trade unionism is a basic element in a future society. 